\title{
Impact of Rhizobial strains Mixture, Phosphorus and Zinc Applications in Nodulation and Yield of Bean (Phaseolus vulgaris L.)
}

\author{
Ali Sabeeh Abdulameer* \\ Received 12, May, 2010 \\ Accepted 25, October, 2010
}

\begin{abstract}
:
Pot experiment was carried out at the College of Agriculture - Baghdad University during autumn season, 2007. Thirteen treatments were formulated to evaluate the effectiveness of four applications of Phosphorus $(0,60,60 \times 2$ and $120 \mathrm{Kg}$ P. $\left.\mathrm{h}^{-1}\right)$ and three applications of Zinc $\left(0,25 \times 2 \mathrm{mg} \mathrm{Zn} . \mathrm{L}^{-1}\right.$ and $\left.50 \mathrm{mg} \mathrm{Zn.} \mathrm{Kg} \mathrm{soil}{ }^{-1}\right)$ along with inoculating seeds of bean with strains mixture 889 and 1865 and noninoculated treatment, on nodulation, yield and protein content in seeds (N\%). The results showed that inoculated plants exceeded on non-inoculated one in all the studied characteristics. While, $\mathrm{P}$ and $\mathrm{Zn}$, applications at the rate of $60 \times 2 \mathrm{~kg} / \mathrm{ha}$ and $25 \times 2 \mathrm{mg} / \mathrm{L}$ respectively, significantly, increased, nodulation, yield, protein content in seeds of bean compared to non-inoculated treatment and Control. The highest grain yield (28.86 g/plant) were obtained with the interaction treatment $(60 \times 2 \mathrm{~kg} \mathrm{P} / \mathrm{ha}+25 \times 2 \mathrm{mg} \mathrm{Zn} / \mathrm{L})$ with Rhizobium inoculation. So, combined application of Rhizobium inoculant along with $60 \times 2 \mathrm{~kg} \mathrm{P} / \mathrm{ha}$ and $25 \times 2 \mathrm{mg} \mathrm{Zn} / \mathrm{L}$ was considered to be the suitable combination of fertilizer for inoculated bean cultivation in silty clay loam soils.
\end{abstract}

\section{Key words: Rhizobial strains, Phosphorus, Zinc, Bean}

\section{Introduction:}

A nodule of leguminous plant is the uniquely differentiated new organ so that the $\mathrm{N}_{2}$ fixation by Rhizobia could function very efficiently. Nodulation starts from the mutual recognition between Rhizobia and a host plant. The Rhizobia induce curling of host root hair and entry into the plant root through an infection thread which originate in a deformed root hair. Subsequently, the cortical cells of root of leguminous plant are made to differentiate, and it is considered to form the new organ, nodule. Instead the photosynthetates depending on the host plant as the energy source in the nodule, Rhizobia [bacteroids] can fix $\mathrm{N}_{2}$ to produce nitrogenous compounds that are necessary for the growth of the host plants and supply them. Various inorganic elements are also necessary with nitrogen so that the Rhizobia may invade into root hair, multiply, form the nodule and express the ability to fix $\mathrm{N}_{2}$. The condition of inorganic nutrition of the leguminous plant can be thought to influence not only the growth of host plant but also nodule formation and $\mathrm{N}_{2}$ fixation [1].

Rhizobial activities and $\mathrm{N}_{2}$ fixation without proper fertilization by phosphorus $(\mathrm{P})$ is depressed because it promotes early root formation and the formation of lateral, fibrous and healthy roots. Leguminous crops meet up their $\mathrm{N}$ requirement through $\mathrm{BNF}$ depending on proper growth, development and also leghemoglobin content of the root nodules. It is supposed that phosphorus is effectively

\footnotetext{
* College of Science for Women - Baghdad University, Baghdad, Iraq
} 
translocated into grain at high rates, since $\mathrm{P}$ is necessary for the production of protein, phospholipids and phytin in bean grain [2]. Phosphorus is one of several elements which affects $\mathrm{N}_{2}$ fixation, it is a principal yield-limiting nutrient in many regions. Rhizobial $\mathrm{P}$ deficiency when there is a $\mathrm{P}$ deficiency in the soil and rhizosphere is a real possibility. In particular; $\mathrm{P}$ appears essential for both nodulation and $\mathrm{N}_{2}$ fixation. Nodules are strong sinks for $\mathrm{P}$ and range in $\mathrm{P}$ content from 0.72 to $1.2 \%$; as a consequence, $\mathrm{N}_{2}$ fixationdependent plants will require more of this element. Nodulation, $\mathrm{N}_{2}$ fixation, and specific nodule activity are directly related to the $\mathrm{P}$ supply [3]

Zinc that is available for plant uptake is present as $\mathrm{Zn}^{2+}$ in the soil solution, or as exchangeable $\mathrm{Zn}$ on cationexchange sites, organically complex $\mathrm{Zn}$ in solution or organically complex $\mathrm{Zn}$ in soil solids. The solubility of $\mathrm{Zn}$ in soils, and the uptake by plants, both fall rapidly as the soil $\mathrm{pH}$ increases. Of the various kinds of inorganic $\mathrm{Zn}$ in the soil solution, $\mathrm{Zn}^{2+}$ is the most common where the $\mathrm{pH}$ is less than 7.7 while $\mathrm{Zn}(\mathrm{OH})^{+}$is predominant where the $\mathrm{pH}$ is between 7.7 and 9.1. High levels of $P$ in soils have been known to intensify $\mathrm{Zn}$ deficiency [4]. The availability of soil $\mathrm{Zn}$ decreases as soil $\mathrm{pH}$ increases; consequently, most $\mathrm{Zn}$ deficiencies are reported on soils with $\mathrm{pH}$ levels higher than 7.0. $\mathrm{Zn}$ deficiencies also are found on soils with high levels of free lime, sandy soils, or soils low in organic matter [5]. As well as, repeated applications of $P$ fertilizer in soils may induce $\mathrm{Zn}$ deficiency [4].

The supply of nutrient(s) via plant roots might be restricted under some soil and environmental conditions such as high $\mathrm{pH}$, high lime content, soil compactness as well as inadequate or excessive irrigation water. Such conditions are prevailing in arid and semi-arid regions, [6] as
Iraq. Iraqi soils generally have free $\mathrm{CaCO}_{3}$, high $\mathrm{pH}$ and low organic matter. Consequently, nutrients disorders in these soils are the most important limiting factor to crop production. Major problems are deficiencies of $\mathrm{N}$ and $\mathrm{P}$. However, recent research has revealed that micronutrient problems are also hampering crop production [7]. Thus, foliar application of nutrient(s) is necessary to compensate the shortage of nutrients via roots or to correct the deficiency of these nutrients or to face the great needs of these elements in leaves [6].

Works on the effect of phosphorus, Zinc and Rhizobium inoculation is scanty or not existing in Iraq. Therefore, the current research was designed to evaluate the effectiveness of four levels of $\mathrm{P}(0,60$, $60 \times 2$ and $120 \mathrm{Kg} \mathrm{P} . \mathrm{h}^{-1}$ ) and three levels of $\mathrm{Zn}\left(0,25 \times 2 \mathrm{mg} \mathrm{Zn} . \mathrm{L}^{-1}\right.$ and $50 \mathrm{mg} \mathrm{Zn} . \mathrm{Kg}^{-1}$ soil) with inoculating seeds of bean by Rhizobium, on nodulation, protein content in seeds $(\mathrm{N}$ $\%)$ and yield. So, it is necessary to examine the effects of different levels of those nutrients and to assess their best combination in terms of enhanced nitrogen fixation and productivity of bean.

\section{Materials and Methods:}

Pot experiment was carried out at College of Agriculture - Baghdad University during autumn season, 2007 using bean (Phaseolus vulgaris L.). The experiment was laid out in Randomized complete Design (RCD) with three replications having each of the pot was filled with $15 \mathrm{~kg}$ of sterile soil by methyl bromide method [8]. Physical and chemical properties of initial soil were estimated by using standard analytical procedures presented in Table 1 
Table1: Physical and chemical properties of initial soil.

\begin{tabular}{|c|c|}
\hline Properties & Values \\
\hline Soil texture & Silt Clay loam \\
\hline Ec ds. ${ }^{-1}$ & 2.40 \\
\hline $\mathrm{pH}$ & 7.82 \\
\hline $\mathrm{O} . \mathrm{M} . \mathrm{g} \cdot \mathrm{kg}^{-1}$ & 11.00 \\
\hline $\mathrm{CaCO} \mathrm{g}^{-1} \mathrm{~kg}^{-1}$ & 244.00 \\
\hline Total N g.kg & 0.70 \\
\hline $\mathrm{P} \mathrm{Cmolc.} \mathrm{kg}$ & 0.201 \\
\hline $\mathrm{K}^{+} \mathrm{meq} / 100 \mathrm{gm}$ & 0.76 \\
\hline $\mathrm{Zn}^{+2} \mathrm{mg} \cdot \mathrm{kg}^{-1}$ & 0.57 \\
\hline
\end{tabular}

Thirteen treatments were as follows; T1:Control, $\quad \mathrm{T} 2: \mathrm{P} 0+\quad \mathrm{Zn0}+R($ Rhizobium $)$, $\mathrm{T} 3: \mathrm{P} 60+\mathrm{Zn} 0+R, \mathrm{~T} 4: \mathrm{P} 60 \times 2+\mathrm{Zn} 0+R, \mathrm{~T} 5: \mathrm{P} 120$ $+\mathrm{Zn} 0+R, \quad \mathrm{~T} 6: \mathrm{P} 0+\mathrm{Zn} 25 \times 2-\mathrm{F}($ Foliar $)+R$, $\mathrm{T} 7: \mathrm{P} 60+\mathrm{Zn} 25 \times 2-\mathrm{F}+R, \mathrm{~T} 8: \mathrm{P} 60 \times 2+\mathrm{Zn} 25 \times 2-$ $\mathrm{F}+R, \mathrm{~T} 9: \mathrm{P} 120+\mathrm{Zn} 25 \times 2-\mathrm{F}+R, \mathrm{~T} 10: \mathrm{P} 0+\mathrm{Zn} 50-$ $\mathrm{S}$ (Surface) $+R, \quad \mathrm{~T} 11: \mathrm{P} 60+\mathrm{Zn} 50-\mathrm{S}+R$, $\mathrm{T} 12: \mathrm{P} 60 \times 2+\mathrm{Zn} 50-\mathrm{S}+R$ and $\mathrm{T} 13: \mathrm{P} 120+$ $\mathrm{Zn} 50-\mathrm{S}+R$.

Four levels of $\mathrm{P}$ are $(0,60,60 \times 2$ and $\left.120 \mathrm{Kg} \mathrm{P}^{-1}\right)^{*}$, and three levels of $\mathrm{Zn}\left(0,25 \times 2 \mathrm{mg} \mathrm{Zn}\right.$. $\mathrm{L}^{-1}$ as foliar

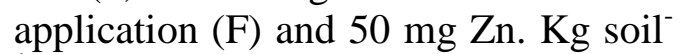
$\left.{ }^{1}\right)^{* *}$ with inoculating seeds of bean by Rhizobium leguminosarum, were applied to the pots according to the treatment combinations. All the experimental Pots were fertilized with $150 \mathrm{~kg} \mathrm{~K} . \mathrm{h}^{-1}$ as potassium sulphate and $40 \mathrm{~kg} \mathrm{~N} . \mathrm{h}^{-1}$ as ammonium nitrate $33 \%$ $\mathrm{N}$ at planting time. Pit based inoculants were prepared with the strains mixture 889 and 1865, from Ebaa center for agricultural research. Seeds were treated with inoculants at $30 \mathrm{~g} / \mathrm{kg}$ of seed, using the Arabic gum as sticker and were sown in the evening. All the agronomic practices like weeding, irrigation, mulching, and plant protection measures were performed as the requirement of the crop. The crop was harvested at full maturity (after 120 days from sowing). Yield data were collected from 3 randomly labeled plants. At the 7th week from sowing, the number of nodules per plant was determined counted by destructive sampling. Harvesting was done, from each pot; selected plants were harvested, and brought to the lab.
The grain yields and protein content in seeds ( $\mathrm{N} \%$ ) were estimated. $\mathrm{P}$ and $\mathrm{Zn}$ content in plant materials were determined. Samples from the seeds and straw were ground and wet digested with a mixture of $\mathrm{H}_{2} \mathrm{SO}_{4}$ and $\mathrm{HClO}_{2}$ acids and left to analysis. Total $\mathrm{N}$ was determined in the dry seeds using the Kjeldahal method according to A.O.A.C., Seeds protein \% was calculated by multiplying the $\mathrm{N} \%$ by the factor 6.25. Standard procedures were followed for recording and analyzed the data on different yield parameters and means were compared using LSD at 5\% level of significance [8].

* The P treatments 60 and $120 \mathrm{Kg} \mathrm{P.} \mathrm{h}{ }^{-}$ ${ }^{1}$ were surface addition in one dose before sowing as calcium super phosphate $\left(15.5 \% \mathrm{P}_{2} \mathrm{O}_{5}\right)$ in liquid form with the irrigation. While, the treatment $60 \times 2$ is surface addition in two equal doses one before planting and the other after 30 days of sowing in the same form.

**The $\mathrm{Zn}$ treatment $25 \times 2 \mathrm{mg} \mathrm{Zn} . \mathrm{L}^{-1}$ (F) is two foliar doses, one after 20 days of sowing and the other after 40 days. While, the $\mathrm{Zn}$ treatment $50 \mathrm{mg}$ $\mathrm{Zn}$. Kg soil ${ }^{-1}$ is surface addition in one liquid dose before sowing. Both, as $\mathrm{ZnSO}_{4}$ prepared solution.

\section{Result and Discussion: \\ Nodulation:}

The result in table (2) showed the absence of all plants, in the treatment that is not inoculated with the Rhizobium specialized on beans in sterile and non-sterile soil, from any nodule. This confirms the success of soil sterilization process and supports the result of laboratory testing of soil used, which showed by the method of dilution and counting in the dishes the absence of Rhizobium specialized on beans in this soil. The control plants (non-inoculated) recorded the lowest rate for the number of nodules, a zero 
nodule . plant ${ }^{-1}$, while the average was 3.67 nodules . Plant ${ }^{-1}$ in the control plants inoculated with mixed strains. Since the application of bacterial inoculum leads to increase the number of root nodules that increase the capability of nitrogen fixation [8]. Pal [9] stated that the process of bacterial inoculation leads to infection with this bacteria, since the bacteria adhesion by these roots and then penetrate the roots, thus increase the number of nodules formed. Hassan [10] got similar results, when he studied the bacteria Bradyrhizobium specialized on mungbean, and Al-Jadir [11] also got similar results in her examination of the Rhizobium specialized on beans.

Table 2: The effect of inoculation on nodulation and seed yield

\begin{tabular}{|c|c|c|}
\hline Characteristics & Inoculated & $\begin{array}{c}\text { Non- } \\
\text { inoculated }\end{array}$ \\
\hline Number of nodules/ plant & 3.67 & 0 \\
\hline $\begin{array}{c}\text { Dry weight of nodules } \\
\text { mg/plant }\end{array}$ & 94.73 & 0 \\
\hline $\begin{array}{c}\text { Protein percentage in seeds } \\
\%\end{array}$ & 17.30 & 13.84 \\
\hline Seed yield g/plant & 5.13 & 2.43 \\
\hline
\end{tabular}

This study showed that the bacterial inoculation resulted in an increase in the rates of dry weight of root nodules that are formed on the roots of beans. The inoculated plants with Rhizobium exceeded on the non-inoculated plants. The non-inoculated control plants, recorded the lowest average of the dry weight of the root nodules was zero mg. Plant ${ }^{-1}$, While the rate was 94.73 mg. Plant ${ }^{-1}$ in the control plants, inoculated with the mixture of strains. Perhaps, this is because the infection did not happen in the non-inoculated plants, and it is occurred in the inoculated plants and the contribution of the nodules formed, in supplying part of the plant need to nitrogen which encouraged the growth of plants and the leaves, thereby increasing the production and supplying of carbonate material necessary for the growth of root nodules formed. This is consistent with that obtained by [11]. Al-Sadi [8] noticed that the number of root nodules and their dry weight had increased from the use of bacterial inoculation by Rhizobium specialized on beans.

Concerning the treatments of zinc, the results of statistical analysis for this study in the table (3) and figure (1) showed significant differences between the zinc treatments, Zn-Foliar* and ZnSurface** in the average of the dry weight of the nodules. The treatment of zinc, Zn-Foliar significantly, exceeded on the ground zinc treatment, ZnSurface, since the averages of dry weight of nodules formed on the roots of beans for zinc treatments $(0, \mathrm{Zn}$ Foliar, Zn-Surface) in plants inoculated with bacterial strain, recorded 282.50, 388.82, $319.01 \quad \mathrm{mg}$. Plant $^{-1}$, respectively. This is consistent with that obtained by each of the $[4,12,13$, $\mathbf{1 4}, \mathbf{1 5}, \mathbf{1 6}]$. The Foliar application with two doses of zinc contributed in improving the overall growth of the plant without any side effects to absorb phosphorus and other elements as in the ground handling of zinc, this encouraged the growth of leaves, production and supplying of carbonate material for the root nodules and increased the concentration of zinc in the plant and the nodules. This has positive impact on the weights of root nodules.

Table 3: Effect of phosphorus and Zinc Applications on dry weight of root nodules mg . plant $^{-1}$.

\begin{tabular}{|c|c|c|c|c|c|}
\hline \multirow[b]{2}{*}{$\mathrm{Zn}$} & \multicolumn{4}{|c|}{$\mathrm{P} \mathrm{Kg} / \mathrm{h}$} & \multirow{2}{*}{$\begin{array}{c}\mathrm{Zn} \\
\text { Mean } \\
\mathrm{s}\end{array}$} \\
\hline & 0 & 60 & $\begin{array}{c}60 \times \\
2\end{array}$ & 120 & \\
\hline 0 & 94.73 & $\begin{array}{c}320.5 \\
8\end{array}$ & $\begin{array}{c}425.9 \\
3\end{array}$ & $\begin{array}{c}288.7 \\
4\end{array}$ & $\begin{array}{c}282.5 \\
0\end{array}$ \\
\hline Foliar* & 142.44 & $\begin{array}{c}428.5 \\
5 \\
\end{array}$ & $\begin{array}{c}581.2 \\
5 \\
\end{array}$ & $\begin{array}{c}403.0 \\
5 \\
\end{array}$ & $\begin{array}{c}388.8 \\
2 \\
\end{array}$ \\
\hline $\begin{array}{c}\text { Surface* } \\
*\end{array}$ & 115.20 & $\begin{array}{c}375.9 \\
7 \\
\end{array}$ & $\begin{array}{c}490.8 \\
5 \\
\end{array}$ & $\begin{array}{c}294.0 \\
2 \\
\end{array}$ & $\begin{array}{c}319.0 \\
1 \\
\end{array}$ \\
\hline P Means & 117.46 & $\begin{array}{c}375.0 \\
3 \\
\end{array}$ & $\begin{array}{c}499.3 \\
4 \\
\end{array}$ & $\begin{array}{c}328.6 \\
0 \\
\end{array}$ & \\
\hline $\begin{array}{l}\text { LSD } \\
0.05\end{array}$ & $\begin{array}{c}\mathrm{P}=19.5 \\
9\end{array}$ & \multicolumn{2}{|c|}{$\mathrm{Zn}=16.96$} & \multicolumn{2}{|c|}{$\mathrm{P} \times \mathrm{Zn}=33.92$} \\
\hline
\end{tabular}


The results of the statistical analysis in the table (3) and figure (1), cleared that phosphorus has positive significant effect by increasing the dry weight of root nodules, in comparison between the treatments of phosphorus and the control, since it recorded the highest weight when it applied the treatment $60 \times 2 \mathrm{~kg} \mathrm{P}$. Ha ${ }^{-1}$, followed by the treatment $60 \mathrm{P}^{-\mathrm{Ha}^{-1}}$ and $120 \mathrm{P}^{-\mathrm{Ha}^{-1}}$, finally the treatment of control, which reached to the followed averages 499.34, 375.03, 328.60, $117.46 \mathrm{mg}$. Plant $^{-1}$, respectively. This agree with Bzheumykhov et al [17] who obtained significant increase in biomass of the root nodules when they applied the inoculation and phosphorus with some other nutrients, depending on the nature of their presence in the soil, and the following researchers whose reached to similar results, like Alkrtani [18] on the plant chickpeas and Chowdhury [19] on the plant Mungbean.

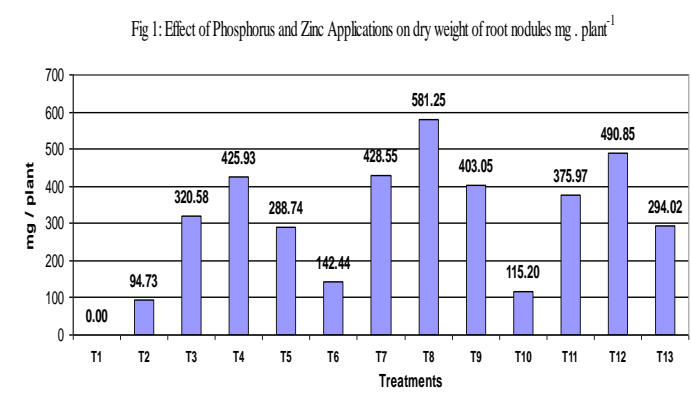

The interaction between the zinc and phosphorus treatments and bacterial inoculation significantly, affected the rate of dry weight of root nodules. Since the interaction treatment $\mathrm{Zn}-$ Foliar $+60 \times 2 \mathrm{~kg} \mathrm{P} . \mathrm{Ha}^{-1}$ gave the highest rate of dry weight of the root nodules, amounting to 581.25 mg. Plant ${ }^{-1}$, which it recorded significant difference in comparison with the control (94.73 mg. Plant ${ }^{-1}$ ). While, the less interaction treatment effect in the dry weight of root nodules recorded in the treatment $\mathrm{Zn}$-Surface + zero $\mathrm{kg} \mathrm{P} . \mathrm{Ha}^{-1}$, by the average 115.20 mg. Plant ${ }^{-1}$. This can be explained by the combination of the positive effects, of the two elements together in advancing the plant growth and evolution of the microbial relationship to higher levels, instead of they had applied separately. So, It may be due to the impact of the two elements and the application methods, that had positive effects in the growth of bacteria and host plant, since that the interaction has increased these effects and thus positively impacted the weight of root nodules [8, 18].

Protein percentage in seeds:

Table (2) showed more superiority of seeds of all plants inoculated with the Rhizobium in protein content to those that did not inoculated. The bacterial inoculation has a positive effect to increase the protein percentage of seeds. As, the seeds of beans of non-inoculated control plants recorded the percentage of protein $13.84 \%$. While this amount rose to $17.30 \%$ in seeds of the inoculated plants, with an increase of $125 \%$. The success of infection to plant beans by Rhizobium and the formation of effective root nodules in the inoculated plants led to increase the nitrogen content of plants, which was reflected on the reached amount of nitrogen to the seeds, which used in making proteins. The treatments that showed the largest concentration of nitrogen in leaves accumulated higher concentration of protein in seeds [20]. [8] obtained similar results, he explained that the application of bacterial inoculum leads to an increase in the number of root nodules and their efficiency in nitrogen fixation and increase the concentration of nitrogen in the seeds of beans and then the proportion of protein in the seeds. These results are compatible with what Alkrtani [18] found that the increase in the concentration of nitrogen in the 
chickpea plants when applying the bacterial inoculum. They are also compatible with these results obtained by Al-Jadir [11] in their study on the beans plants as the inoculation treatment was significantly superior on non-inoculated treatment in the proportion of seeds and the protein at the level 0.01 and 0.0001 respectively.

Table 4: Effect of phosphorus and Zinc Applications on Protein percentage in seeds $(\%)$

\begin{tabular}{|c|c|c|c|c|c|}
\hline \multirow{2}{*}{$\mathrm{Zn}$} & \multicolumn{4}{|c|}{$\mathrm{P} \mathrm{Kg} / \mathrm{h}$} & \multirow{2}{*}{$\begin{array}{c}\mathrm{Zn} \\
\text { Means }\end{array}$} \\
\hline & 0 & 60 & $60 \times 2$ & 120 & \\
\hline 0 & 17.30 & 21.74 & 22.74 & 20.24 & 20.51 \\
\hline Foliar* & 22.29 & 24.93 & 26.45 & 23.43 & 24.28 \\
\hline Surface** & 19.76 & 22.04 & 23.61 & 21.69 & 21.78 \\
\hline P Means & 19.78 & 22.90 & 24.27 & 21.79 & \\
\hline LSD 0.05 & $\mathrm{P}=0.83$ & \multicolumn{2}{|c|}{$\mathrm{Zn}=0.72$} & \multicolumn{2}{|c|}{$\mathrm{P} \times \mathrm{Zn}=1.43$} \\
\hline
\end{tabular}

The results in table (4) and figure (2) show the positive role of zinc in increasing the proportion of protein in the seed significantly. The treatments of zinc surpassed significantly in this characteristic on the treatment of control. As, the average of protein percentage in the seeds of inoculated plants at the treatments $(0, \mathrm{Zn}$-Foliar, Zn-Surface) were 20.51, 24.28, $21.77 \%$, respectively. Both Kassab [12] and [13] have obtained similar results who recorded that the application of zinc spray increased atmospheric nitrogen fixation and the proportion of protein in the seeds through the improvement of all measurements of plant growth, roots and there by increasing the density of root growth in soil and increase the numbers of the nodules by increasing the leaf area, thus improve the production of carbonate compounds and supplying to nodules. While Yadav \& Shukla [14] recorded that adding zinc to the soil increased atmospheric nitrogen fixation by increasing the number of nodules and that because reducing the proportion of $\mathrm{Na} / \mathrm{P}$ and increase the activity of bacteria in the rhizosphere. This was reflected positively on the proportion of protein in the seeds of chickpea plants.

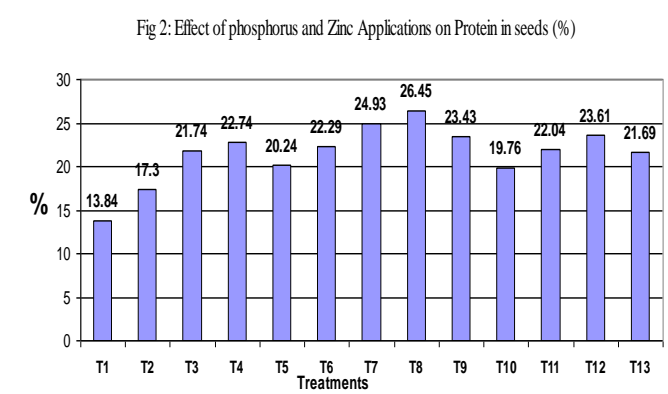

The interaction among zinc, phosphorus and bacterial inoculum in general resulted in obtaining positive significant differences in the percentage of protein in the seeds. The treatment of interaction $\mathrm{Zn}$-Foliar + $60 \times 2 \mathrm{~kg} \mathrm{P} . \mathrm{Ha}^{-1}$ gave the highest rate at $26.45 \%$ followed by the treatment of interaction $\mathrm{Zn}$-Foliar $+60 \mathrm{~kg} \mathrm{P}$. $\mathrm{Ha}^{-1}$ with significant difference, and decline at the amount of $5.75 \%$ approximately. As, it recorded $24.93 \%$. On the other hand the control treatment gave the lowest protein percentage in the seed, which amounted to $17.30 \%$.

\section{Seed yield per plant}

The results of the current study in table (5) and figure (3) show that the bacterial inoculation has a positive role in increasing the weight of the seeds of the plant. The inoculated plants surpassed in this capacity on noninoculated plants. They have made the proportion of an increase of $211.11 \%$ compared to the treatment of control (without inoculation). The average seed weight of treatments (without inoculation, inoculation) was 2.43 , 5.13 g. Plant ${ }^{-1}$, respectively. The application of bacterial inoculum had increased the weight of the seed through supplying plants with atmospheric fixed nitrogen biologically. This may be due to the high ability of Rhizobium bacteria used in inoculation in nitrogen fixation and plant benefit from it, as well as their impact on increasing the capability of 
roots to absorb of various nutrients. The good supplying of the nitrogen for the plant is also important for the absorption of other elements [20]. These results of the impact of bacterial inoculation in the yield of beans are compatible with those obtained by AlJadir [11] when studying the effect of applying bacterial inoculum on the plant beans.

By noting table (5), figure (3) and the results of statistical analysis, the average weight of seeds of plants cultivated at the level of zinc at $\mathrm{Zn}$ Foliar with the inoculated plants can be shown significantly superior to the rest of the levels of zinc and exceeding of zinc $\mathrm{Zn}$-Surface significantly on the treatment of control. The total weight of seeds at the three levels of zinc $(0$, Zn-Foliar, Zn-Surface) was 13.21, 19.22, 15.48 g. Plant ${ }^{-1}$, respectively. Each of $[4,12,13]$ got similar results. It was noted that the application of zinc spray to the beans rose concentration in shoots. This increase was exploited in the composition of plant compounds that activate the enzyme action and thus improve the yield of the plant Krishna [21].

Table 5: Effect of phosphorus and Zinc Applications on Seed yield $\mathrm{g}$. plant $^{-1}$

\begin{tabular}{|r|r|r|r|r|r|}
\hline \multirow{2}{*}{$\mathrm{Zn}$} & \multicolumn{4}{|c|}{$\mathrm{P} \mathrm{Kg} / \mathrm{h}$} & $\begin{array}{r}\mathrm{Zn} \\
\text { Means }\end{array}$ \\
\cline { 2 - 5 } & 0 & 60 & $60 \times 2$ & 120 & 13.90 \\
\hline 0 & 5.13 & 15.68 & 21.74 & 13.04 & 18.53 \\
\hline Foliar* & 8.69 & 18.98 & 28.86 & 17.56 & 13.48 \\
\hline Surface** & 6.82 & 17.38 & 24.34 & 13.38 & 15.48 \\
\hline P Means & 6.88 & 17.35 & 24.98 & 14.66 & \\
\hline LSD 0.05 & $\mathrm{P}=1.57$ & \multicolumn{3}{|c}{$\mathrm{Zn}=1.36$} & \multicolumn{3}{|c|}{$\mathrm{P} \times \mathrm{Zn}=2.71$} \\
\hline
\end{tabular}

Table (5), figure (3) and the results of statistical analysis showed the impact of examined phosphorus levels in seed weight. The statistical analysis showed a significant difference between the levels of phosphorus, where the impact of phosphorus increased significantly in seed weight and excellence the level $60 \times 2 \mathrm{~kg} \mathrm{P}$. $\mathrm{Ha}^{-}$ ${ }^{1}$ significantly on the rest of levels, followed by the level of phosphorus, $60 \mathrm{~kg} \mathrm{P} . \mathrm{Ha}^{-1}$, and then level $120 \mathrm{P}$. Ha ${ }^{1}$ and finally the level of control (zero $\mathrm{P}$. $\left.\mathrm{Ha}^{-1}\right)$. The average weights at the phosphorus treatments were $(0,60$, 60x2, 120) kg P. Ha ${ }^{-1}$ 6.88, 18.27, 24.06, 14.66 gm. Plant ${ }^{-1}$, respectively. [2] and [18] had similar results who received significant increase in the yield seeds of two varieties of beans by the addition of fertilizer phosphorus

Fig 3: Effect of phosphorus and Zinc Applications on Seed yield g . plant

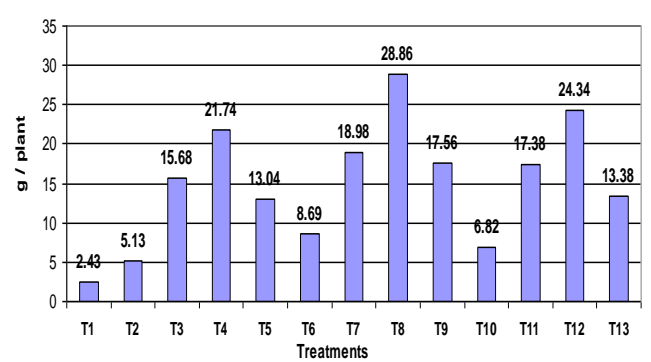

In conclusion the interaction among each of the zinc, phosphorus and bacterial inoculum lead to the superiority of the treatment of interaction $\mathrm{Zn}-$ Foliar $+60 \times 2 \mathrm{~kg} \mathrm{P}$. $\mathrm{Ha}^{-1}$ on the rest of the treatments which led to the increasing of seed weight. Its average was 28.86 gm- yield. Plant ${ }^{-1}$, followed by treatment of interaction $\mathrm{Zn}$-Foliar $+60 \mathrm{~kg} \mathrm{P}$. $\mathrm{Ha}^{-1}$ as averaged 21.74 gm. Plant ${ }^{-1}$, while the control treatment gave the lowest rate where the weight of the seeds was $5.13 \mathrm{gm}$. Plant $^{-1}$. On the other hand the control treatment without inoculation gave less weight of the seeds which was 2.43 gm. Plant ${ }^{-1}$. These results show that this interaction encouraged the accumulation of the positive effects of direct and indirect effects on each of the Rhizobium and plant which was reflected on each of the percentage of protein in the seed $(\mathrm{N} \%)$ and growth and the yield of the seeds.

\section{References:}

1. Yamakawa T., Okuda N. and Taira K. 2008. The Difference between the Micronutrients Content of Seedling's Root and Root Hair in 
Several Plant Species. J. Fac. Agr., Kyushu Univ.- Japan, 53 (1), 3338

2. Rahman M.M., Bhuiyan M.M.H., Sutradhar G.N.C., Rahman M.M. and Paul A.K. 2008. Effect of Phosphorus, Molybdenum and Rhizobium Inoculation on Yield and Yield Attributes of Mungbean. Int. J. Sustain. Crop Prod. 3(6):2633.

3. Zahran, H. H. 2000, RhizobiumLegume Symbiosis and Nitrogen Fixation under Severe Conditions and in an Arid Climate. Department of Botany, Faculty of Science, Beni-Suef, 62511 Egypt Microbiology and Molecular Biology Reviews, American Society for Microbiology. p. 968989

4. Osotsapar Y., 2005. Micronutrients in Crop Production in Thailand. Department of Soils, Faculty of Agriculture, Kasetsart University, Kamphaeng Sean, Nakorn Pathom 73140, Thailand

5. Davis, J.G. and Brick, M.A. 2009. Fertilizing Dry Beans. Colorado State University Extension. Reviewed 4/09. USA. no. 0.539, 1 (4/09).

6. Hussein, M.M., Abd El-Kader, A.A. and Mona A. M.. 2009. Mineral Status of Plant Shoots and Grains of Barley under Foliar Fertilization and Water Stress. Research Journal of Agriculture and Biological Sciences, 5(2): 108115.

7. Nasef, M.A.; Nadia, M. B. and Amal, F. A. 2006. Response of Peanut to Foliar Spray with Boron and /or Rhizobium inoculation. Journal of Applied Sciences Research, 2(12): 1330-1337.

8. Al-Sadi A. S., 2007. Effect of Potassium and Cobalt on Rhizobium Efficiency and on Growth and Yield of Phaseolus vulgaris L. M.Sc. Thesis, College of Agriculture - Soil \& Water Sciences Dept. Iraq.

9. Pal, P.K., 1986. Impact of Rhizobial Strains and Micronutrients on Grain Yield of Peanut. Environment and Ecology. 4: 4, 721-724.

10. Hassan, A. E., 2004. Effect of Salinity ON Bradyrhizobium spp. Efficiency on Mungbean Plant. M.Sc. Thesis, College of Agriculture - Soil \& Water Sciences Dept. Iraq.

11. Al-Jader, B. M., 2006. Effect of Feul oil on Rhizobium Efficiency and on Growth and Yield of Phaseolus vulgaris L. and Its Antibiotics Resistance. M.Sc. Thesis, College of Agriculture Soil \& Water Sciences Dept. Iraq.

12. Kassab, O.M., 2005. Soil moisture stress and micronutrients foliar application effects on the growth and yield of mungbean plants. J. Agric. Sci., Mansoura University, 30: 247-256.

13. Thalooth, A.T., Tawfik, M.M. and Magda, H. M. 2006. A Comparative Study on the Effect of Foliar Application of Zinc, Potassium and Magnesium on Growth, Yield and Some Chemical Constituents of Mungbean Plants Grown under Water Stress Conditions. World Journal of Agricultural Sciences 2 (1): 37-46.

14. Yadav, O. P. and U. C. Shukla 1983. Effect of zinc on nodulation and nitrogen fixation in chickpea (Cicer arietinum L.). J. Aagric. Sci., Camb., 101: 559-563.

15. Smith, S. R. 1997. Rhizobium in soils contaminated with copper and zinc following the long-term application of sewage sludge and other organic wastes. Soil Biol. Bioch. 29:1475-1489.

16. O'Hara, G. W. 2001. Nutritional constraints on root nodule bacteria 
17. affecting symbiotic nitrogen fixation : a review. Aust. J. of Exp. Agri., 41, 417-433.

18. Bzheumykhov, V. S.; Kashukoev, M. V.; Tokbaev, M. M., 1999. Nitrogen-fixing activity of lucerne in relation to soil moisture, activity of Rhizobium strain and supply of mineral nutrition elements. Moscow Agricultural Academy, Russia. CABI Pub. Inter. New York USA,

19. Alkrtani, R. 2005. Effect of iron and phosphorus on Rhizobium Efficiency and on Growth and Yield of cowpea. M.Sc. Thesis, College of Agriculture - Soil \& Water Sciences Dept. Iraq.

20. Chowdhury, M.M. 1996. Response of mungbean [Vigna radiata (L.)
Wilczek] to Rhizobium inoculation and phosphorus application. An unpublished M.S. (Soil Science) Thesis, Institute of Postgraduate Studies in Agriculture (IPSA), Gazipur, Bangladesh.

21. Tanaka, R.T., H. A.A. Marcarenhas, T. Muraoka and P.B. Gallo. 1997. Changes in soybean quality resulting from application of lime and potassium fertilizer. In: Plant nutrition for sustainable food production and environment. T. Ando (Eds.), Brazil. p. 943-944.

22. Krishna, S., 1995. Effect of sulphur and zinc application on yield, $\mathrm{S}$ and $\mathrm{Zn}$ uptake and protein content of mung (green gram). Legume Res., 18: 89-92.

\section{تأثير خليط اللقاح البكتيري وكل من الفسفور والزنك في تكوين العقد الجذرية

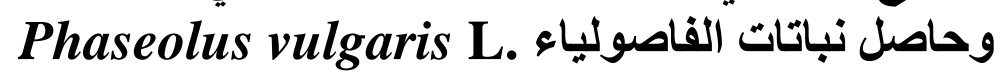

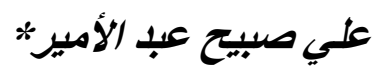

*كلية العلوم للبنات \جامعة بغداد

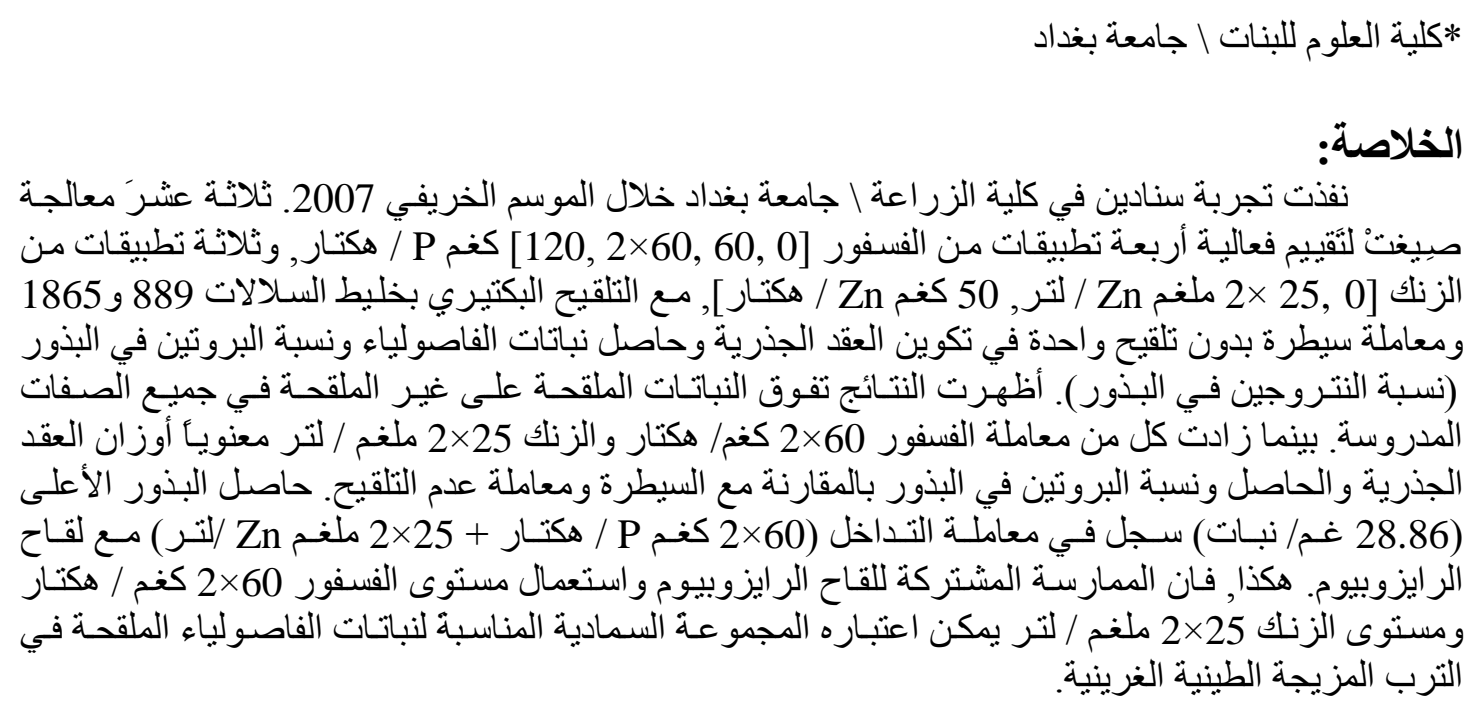

